\title{
Absence of Antidiabetic and Hypolipidemic Effect of Gymnema sylvestre in Non-diabetic and Alloxan-Diabetic Rats
}

\author{
Ricardo Galletto*, Vera Lúcia Dias Siqueira, Edilene Bega Ferreira, Arildo José Braz \\ Oliveira and Roberto Barbosa Bazotte \\ Departamento de Farmácia e Farmacologia; Universidade Estadual de Maringá; Av. Colombo, 5790; 87020-900; \\ Maringá - PR - Brazil
}

\begin{abstract}
In this study we investigated the antidiabetic and hypolipidemic potential of dried powdered leaves of Gymnema sylvestre (GS). The acute effect of GS administered by oral gavage on glucose blood level of and lipids in nondiabetic and alloxan-diabetic rats were investigated in the following conditions: a) after a balanced meal; $b$ ) after the ingestion of $1000 \mathrm{mg} / \mathrm{kg}$ amylose or $1000 \mathrm{mg} / \mathrm{kg}$ glucose; c) after the ingestion of a mixture of $12 \mathrm{~mL} / \mathrm{kg} \mathrm{soybean}$ oil $+1 \%$ cholesterol (SOC). In addition, the effect of the treatment with GS during two (sub-acute) or four weeks (chronic) on body weight, food and water ingestion, glucose blood level and lipids in non-diabetic and alloxandiabetic rats were measured. The dose of GS utilized in the majority of the experiments, i.e., $30 \mathrm{mg} / \mathrm{kg}$, corresponds to that given to treat diabetes in Brazil. GS acutely did not influence the elevation of glycemia promoted by a balanced meal or by the administration of amylose or glucose; but promoted more intense $(P<0.05)$ elevation of serum lipids after the administration of SOC. Moreover, the sub-acute and chronic treatment with GS in nondiabetic and alloxan-diabetic rats did not change: a) the body weight gain; b) food and water ingestion; c) the blood level of glucose and lipids. Thus we concluded that GS, at least in the form commercialized in the Brazil, i.e., dried powdered leaves, require further experimental and clinical trials before being recommended to treat diabetes and hyperlipidemia.
\end{abstract}

Key words: Gymnema sylvestre; herbal therapies; diabetes; asclepideceae

\section{INTRODUCTION}

It is quite clear that the use of herbal products to treat type 2 diabetes mellitus has highly increased very much in the last few years (Day, 1998; Grover et al., 2002). However, scientific and medical evaluation to assess their efficacy supporting the presumed antidiabetic effect is usually absent or requires further investigations (Bailey and Day, 1989). In contrast, several investigators reported antidiabetic properties of
Gymnema sylvestre R. Br., Asclepideceae (GS), not only in rats (Shanmugasundaram et al., 1990; Okabayashi et al., 1990) but also in humans (Shanmugasundaram et al., 1990 ; Hirata et al., 1992). The mechanisms by which GS produce antidiabetic effects include: recovery of beta cells (Shanmugasundaram et al., 1990 $\mathrm{a,b}$; Baskaran et al., 1990), inhibition of glucose absorption (Hirata et al., 1992; Shimizu et al., 1997), stimulation of insulin release (Persaud et. al., 1999; Sugihara et al., 2000) and increased glucose

\footnotetext{
* Author for correspondence
} 
tolerance (Kar et al., 1999). Furthermore, the lipidlowering properties have been described (Shigematsu et al., 2001 a Wang et al., 1998). However, it must be considered that all these studies were performed using a mixture of glycosides (Yoshikawa et al., 1997 $7_{\mathrm{a}}$; Shimizu et al., 1997), a fraction denominated $\mathrm{GS}_{4}$ (Shanmugasundaram et al., 1990 ${ }_{\mathrm{a}}$; Okabayashi et al., 1990; Baskaran et al., 1990; Persaud et al., 1999), alcoholic extract of leaves (Chattopadhyay, 1998; Chattopadhyay, 1999; Kar et al., 1999; Kar et al., 2003) and gymnemic acid (Hirata et al., 1992; Sugihara et al., 2000; Murakami et al., 1996). On other hand, in Brazil, capsules containing dried powdered leaves of GS, highly commercialized in pharmacies and stores, is probably the most popular commercial herbal product to treat diabetes. However, there are few scientific evidence (Shanmugasundaram et al., 1983) supporting that this herbal preparation could contribute to a beneficial effect in diabetic patients. Thus, the present study was carried out to verify if the dried powdered leaves of GS consumed in Brazil could show antidiabetic properties as previously described for several fractions of GS (Shanmugasundaram et al., 1990; Kar et al., 1999). Moreover, the hypolipidemic effect of GS was investigated.

\section{MATERIALS AND METHODS}

\section{Plant material}

Capsules containing dried powdered leaves of Gymnema sylvestre R. Br., Asclepideceae from Herbarium Laboratories (Colombo, PR, Brazil) were used. Immediately before the administration, the contents of the capsules (Lot 295981) were removed and dissolved in water.

\section{Animals and GS treatment}

Wistar rats (Rattus norvegicus), weighing 200-250 $\mathrm{g}$, receiving food (Nuvital ${ }^{\circledR}$ commercial chow) and water ad libitum were utilized. The animals were individually caged in an environment in which the photoperiod and temperature were controlled. The manipulation of the animals followed the Brazilian animal protection law. All substances were administered orally through a gastric tube. The GS dose used in the majority of the experiments, i.e., $30 \mathrm{mg} / \mathrm{kg}$, corresponded to that given to treat type 2 diabetes in Brazil. The animals were not included in the study at the same time, but in several continuous experiments which were classified as: acute (the studies were performed after a unique GS administration), subacute (the rats received GS twice a day during two weeks) and chronic treatment (the rats received GS twice a day during four weeks).

\section{Acute effect of $30 \mathrm{mg} / \mathrm{kg}$ GS on glycemia and} serum lipids during a balanced meal

Rats were trained to eat a single meal daily at 8:00-10:00 (MF rats) during seven days. On day 8, immediately before the meal, the MF rats were divided in two groups, one received GS (experimental group), the other received water (control group, i.e, COG group). After water or GS administration at 8:00 a.m., all rats received a fixed amount of food, i.e., $5 \mathrm{~g}$ of commercial chow which corresponded approximately $70 \%$ of the amount of food ingested by MF rats on the day 8 of feeding training. This procedure and previous feeding training was performed to obtain rats with the ability to ingest the same amount of food at the same period of time (about 30 minutes) like a human meal (Bazotte et al., 2000). Immediately after the meal, the rats were subdivided into 4 subgroups, i.e., rats which were killed by decapitation at 0 (COG - 0 minute and GS - 0 minute) and 30 (COG - 30 minutes and GS - 30 minutes) after the meal. Blood was collected and glucose serum level (Bergmeyer and Bernt, 1974), triglycerides (Bucolo and David, 1973), cholesterol (Allain et al., 1974) and total lipids (Postma and Stroes, 1968) were measured. The results are presented in the Table 1.

Acute effect of $1000 \mathrm{mg} / \mathrm{kg}$ GS on the elevation of glycemia promoted by the administration of $1000 \mathrm{mg} / \mathrm{kg}$ amylose (AM)

Overnight fasted rats which received: a) water (COG group); b) AM; c) GS or d) $\mathrm{AM}+\mathrm{GS}$ (administered simultaneously) were compared. Positive control was represented by a group which received simultaneous administration of 12 $\mathrm{mg} / \mathrm{kg}$ acarbose $(\mathrm{AC})+\mathrm{AM}$. All rats were killed by decapitation 30 minutes after administration of these substances. Blood was collected and glycemia (Bergmeyer and Bernt, 1974) was measured. The results are presented in the Table 2. 
Acute effect of $1000 \mathrm{mg} / \mathrm{kg}$ GS on the elevation of glycemia promoted by the administration of $1000 \mathrm{mg} / \mathrm{kg}$ glucose (Gluc)

Overnight fasted rats which received: a) water (COG group); b) Gluc; c) GS or d) GS + Gluc (administered simultaneously) were compared. All rats were killed by decapitation 30 minutes after the administration of these substances. Blood was collected and glycemia (Bergmeyer and Bernt, 1974) was measured. The results are presented in the Table 3.

Acute effect of $30 \mathrm{mg} / \mathrm{kg} \mathrm{GS}$ on the elevation of serum lipids promoted by the administration of $12 \mathrm{~mL} / \mathrm{kg}$ soy oil $+1 \%$ cholesterol (SOC)

Overnight fasted rats which received: a) water (COG group); b) SOC; c) GS; d) GS + SOC were compared. GS + SOC group was subdivided in 3 subgroups composed by rats which received GS 30 minutes before (- GS 30 minutes), simultaneously (GS 0 minute) and 30 minutes after administration of SOC (GS 30 minutes). The rats were killed by decapitation 4 hours after administration of SOC and the blood was collected to measure the triglycerides serum level (Bucolo and David, 1973), cholesterol (Allain et al., 1974) and total lipids (Postma and Stroes, 1968). The results are presented in the Table 4.

Effect of the sub-acute (two weeks) treatment with $30 \mathrm{mg} / \mathrm{kg}$ GS on the glucose and triglycerides blood level, body weight, daily food and water intake in non-diabetic and alloxan-diabetic rats

Diabetes was obtained by an iv, injection of 45 $\mathrm{mg} / \mathrm{kg}$ of alloxan. Thus, 30 days after the injection of alloxan the rats that showed blood level of glucose higher than $200 \mathrm{mg} / \mathrm{dL}$ were selected to receive GS or water (COG group). Immediately before starting the treatment the body weight, daily food and water ingestion were measured. Additionally, a blood sample from the tail was collected to measure serum glucose (Bergmeyer and Bernt, 1974) and triglycerides (Bucolo and David, 1973). Thus, from first day until day 14, GS $(15 \mathrm{mg} / \mathrm{kg})$ was administered twice a day $(8: 00$ a.m. and 5:00 p.m.). COG received water with no additions. On day 14 the body weight, daily food and water ingestion were measured again, and immediately after the second administration (5:00 p.m.) of GS, food was removed. Thus, in the next day (8:00 a.m.) a blood sample from tail was collected again to measure the glucose blood level
(Bergmeyer and Bernt, 1974) and triglycerides (Bucolo and David, 1973). The results from nondiabetic and alloxan-diabetic rats are presented in the Table 5 and 6 respectively.

Effect of the chronic treatment (four weeks) with $30 \mathrm{mg} / \mathrm{kg}$ GS on the triglycerides and glucose blood level, body weight, daily food and water intake in non-diabetic and alloxandiabetic rats

The treatment with GS previously described was maintained for more two additional weeks and the parameters previously described were measured again. The results are presented in the Table 7.

The results in the text are presented as standard error of the mean (SEM). Significance of differences between the groups was determined by Student's t-test or ANOVA. A 95\% level of confidence $(\mathrm{p}<0.05)$ was accepted for all comparisons.

\section{RESULTS}

In the first set of experiments, the acute effect of GS on the elevation of glycemia promoted by a balanced meal in MF rats was investigated. As shown in Table 1 , GS $(30 \mathrm{mg} / \mathrm{kg})$ did not affect glucose blood level, cholesterol, triglycerides and total lipids, immediately and 30 minutes after a meal with a standard laboratory diet. However, if GS $30 \mathrm{mg} / \mathrm{kg}$ was replaced by GS $1000 \mathrm{mg} / \mathrm{kg}$ a clear hyperglycemia was observed (results not shown).

In the second set of experiments, the acute effect of GS on the elevation of glycemia promoted by the administration of $1000 \mathrm{mg} / \mathrm{kg}$ amylose (AM) in overnight fasted rats was investigated. As shown in Table 2, differently of $12 \mathrm{mg} / \mathrm{kg}$ acarbose, 1000 $\mathrm{mg} / \mathrm{kg}$ GS did not impair the elevation of glycemia promoted by AM. Similar results were obtained if $1000 \mathrm{mg} / \mathrm{kg} \mathrm{GS}$ was replaced by $500 \mathrm{mg} / \mathrm{kg} \mathrm{GS}$ or $30 \mathrm{mg} / \mathrm{kg}$ GS (results not showed). In agreement with these results $1000 \mathrm{mg} / \mathrm{kg}$ GS did not impair the elevation of glycemia promoted by the administration of $1000 \mathrm{mg} / \mathrm{kg}$ glucose (Table 3 ).

In the third set of experiments, the acute effect of $30 \mathrm{mg} / \mathrm{kg}$ GS administered 30 minutes before, simultaneously or 30 minutes after the administration of SOC on the elevation of serum lipids in overnight fasted rats was investigated. As shown in Table 4, GS promoted more intense 
$(\mathrm{P}<0.05)$ elevation of triglycerides and total lipids, but not total cholesterol.

In the fourth set of experiments the effect of the treatment during two weeks with $30 \mathrm{mg} / \mathrm{kg}$ GS on blood level of glucose and triglycerides, body weight, daily food and water intake were investigated. As shown in Table 5 (non-diabetic rats) and Table 6 (alloxan-diabetic rats) these parameters were not affected by the treatment with GS. Similar results were obtained if the treatment with GS was expanded to 4 weeks (Table 7).

\section{DISCUSSION}

Type 2 diabetes mellitus, which accounts for about $90 \%$ of all diabetes, is possibly the world's fastest growing metabolic disease. Because type 2 diabetes mellitus does not show clear symptoms and the absence of an effective treatment allied to unclear symptons is a risk factor for hypertriglyceridemia, hypercholesterolemia, atherosclerosis, hypertension, myocardial infarction, ischemic attack, stroke, gangrene, impotence, constipation, nephropathy, retinopathy, cataract etc. For this reason traditional antidiabetic plants, particularly in the form used by the population needs a further investigation, considering that untreated type 2 diabetes mellitus is a very dangerous conditions for the patient. In this way, we investigate if GS, in the form commercialized in the Brazilian pharmacies and stores show the reputedly antidiabetic properties claimed by the manufacturer.

GS acutely did not influence the elevation of glycemia promoted by a balanced meal (Table 1), by the administration of amylose (Table 2) or glucose (Table 3); but promoted more intense $(\mathrm{P}<0.05)$ elevation of serum lipids after the administration of SOC (Table 4). Moreover, the sub-acute and chronic treatment with GS in nondiabetic (Table 5 and 7) and alloxan-diabetic rats (Table 6 and 7) did not change: a) the body weight gain; b) food and water ingestion; c) lipids and glucose blood level. On the other hand, in spite of alloxan-diabetic rats which received GS during 2 weeks (Table 6) showed lower $(\mathrm{P}<0.05)$ level of $\mathrm{TG}$, this difference is not maintained until 4 weeks of treatment with GS (Table 7). In addition the level of TG in alloxan-diabetic rats after 2 (Table 6) or 4 weeks (Table 7) of treatment was higher $(\mathrm{P}<0.05)$ when compared with non-diabetic rats (Table 6 and 7 ).

Thus, in contrast with several studies which demonstrated antidiabetic (Shanmugasundaram et al., 1990 ; Kar et al., 1999) and hypolipidemic (Shigematsu et al., 2001 a Wang et al., 1998) properties to GS, we did not find any effect not only after acute administration but also during a subacute ( 2 weeks) and chronic (4 weeks treatment with GS). The absence of acute, sub-acute and chronic effects could not be attributed to a limitation of our experimental rat model since a clear antidiabetic and antihyperlipidemic effect was routinely obtained in our lab with conventional doses of classical antihyperlipidemic (Orlistat, Sinvastatin, Fibrates: unpublished results), antihyperglycemic (Acarbose: see Table 2) and hypoglycemic (Insulin) drugs (Souza et al., 2001).

The difference from our results and majority of studies showing antidiabetic and antihyperlipidemic properties for GS could be attributed to the fact that these investigators used a mixture of glycosides (Yoshikawa et al., 1997; Shimizu et al., 1997), a fraction named $\mathrm{GS}_{4}$ (Shanmugasundaram et al., 1990 a Okabayashi et al., 1990; Baskaran et al., 1990; Persaud et al., 1999), alcoholic extract of leaves (Chattopadhyay, 1998; Chattopadhyay, 1999; Kar et al., 1999; Kar et al., 2003) and gymnemic acid (Hirata et al., 1992; Sugihara et al., 2000; Murakami et al., 1996).

Thus, our results suggest that GS, at least in the form commercialized in the Brazil require further experimental and clinical trials before to be recommended to treat diabetes.

Table 1 - Effect of the acute administration (oral gavage) of $30 \mathrm{mg} / \mathrm{kg}$ Gymnema sylvestre (GS) on glycemia (GL), triglyceridemia (TG), cholesterolemia (TC) and total lipids (TL) after a balanced meal in trained meal-fed (MF) rats.

\begin{tabular}{cccccc}
\hline mg/dL & COG - 0 minute & GS - 0 minute & COG - 30 minutes & \multicolumn{1}{c}{ GS - 30 minutes } \\
\hline GL & $108.4 \pm 7.1$ & $117.2 \pm 3.1^{\mathrm{a}}$ & $96.17 \pm 6.8$ & $114.3+10.5^{\mathrm{a}}$ \\
TG & $61.3 \pm 7.2$ & $83.6 \pm 3.9^{\mathrm{a}}$ & $70.4 \pm 5.9$ & $69.2^{\mathrm{a}}+3.4^{\mathrm{a}}$ \\
TC & $84.9 \pm 2.5$ & $88.4 \pm 3.6^{\mathrm{a}}$ & $85.1+2.4$ & $84.9 \pm 3.4^{\mathrm{a}}$ \\
TL & $249.9 \pm 6.1$ & $294.5 \pm 12.4^{\mathrm{a}}$ & $269.5 \pm 7.9$ & $259.1 \pm 11.7^{\mathrm{a}}$ \\
\hline
\end{tabular}

The results are presented as mean \pm standard error of the mean. $n=10 .{ }^{a} \mathrm{P}>0.05$ for comparisons between COG - 0 minute vs. GS 0 minute and COG - 30 minutes vs. GS - 30 minutes. 
Table 2 - Effect of the acute administration of $1000 \mathrm{mg} / \mathrm{kg}$ Gymnema sylvestre (GS). on the elevation of glycemia (GL) promoted by the administration of $1000 \mathrm{mg} / \mathrm{kg}$ amylose (AM) in overnight fasted rats.

\begin{tabular}{c|c|c|c|c}
\hline COG & AM & GS & GS + AM & AC + AM \\
\hline $72.1 \pm 2.1$ & $112.2 \pm 3.4^{\mathrm{b}}$ & $60.3 \pm 3.5^{\mathrm{a}}$ & $86.9+4.5^{\mathrm{b} . \mathrm{c}}$ & $63.2+5.1^{\mathrm{a}}$
\end{tabular}

The results $(\mathrm{mg} / \mathrm{dL})$ are presented as mean \pm standard error of the mean. $\mathrm{n}=12{ }^{\mathrm{a}} \mathrm{P}>0.05 .{ }^{\mathrm{b}} \mathrm{P}<0.05$ vs. COG group. ${ }^{\mathrm{c}} \mathrm{P}<0.05$ for comparison between GS + AM and AC + AM.

Table 3 - Effect of the acute administration of $1000 \mathrm{mg} / \mathrm{kg}$ Gymnema sylvestre (GS). on the elevation of glycemia promoted by the administration of $1000 \mathrm{mg} / \mathrm{kg}$ glucose (Gluc) in overnight fasting rats.

\begin{tabular}{c|c|c|c}
\hline COG & Gluc & GS & GS + Gluc \\
\hline $58.3 \pm 3.14$ & $110.0 \pm 10.47^{\mathrm{b}}$ & $62.1 \pm 5.29^{\mathrm{a}}$ & $103.0 \pm 6.32^{\mathrm{b}}$ \\
\hline
\end{tabular}

The results $(\mathrm{mg} / \mathrm{dL})$ are presented as mean \pm standard error of the mean. $. \mathrm{n}=5{ }^{\mathrm{a}} \mathrm{P}>0.05 .{ }^{\mathrm{b}} \mathrm{P}<0.05$ vs. COG group.

Table 4 - Effect of the acute administration of $30 \mathrm{mg} / \mathrm{kg}$ Gymnema sylvestre (GS) on the elevation of serum lipids promoted by the administration of $12 \mathrm{~mL} / \mathrm{kg}$ soy oil $+1 \%$ cholesterol (SOC).

\begin{tabular}{|c|c|c|c|c|c|}
\hline \multirow[b]{2}{*}{ mg/dL } & \multirow[b]{2}{*}{ COG } & \multirow[b]{2}{*}{ SOC } & \multicolumn{3}{|c|}{$\mathrm{SOC}+\mathrm{GS}$} \\
\hline & & & -30 minutes & O minute & 30 minutes \\
\hline TG & $67.4 \pm 9.89^{b}$ & $307.4 \pm 51.11$ & $546.9 \pm 16.01^{b}$ & $631.0 \pm 12.25^{b}$ & $519.3 \pm 13.21^{\mathrm{b}}$ \\
\hline $\mathrm{TC}$ & $98.84 \pm 2.30^{\mathrm{a}}$ & $121.4 \pm 7.33$ & $111.0 \pm 5.82^{\mathrm{a}}$ & $114.4 \pm 2.31^{\mathrm{a}}$ & $109.7 \pm 4.29^{a}$ \\
\hline $\mathrm{TL}$ & $292.6 \pm 26.32^{b}$ & $606.6 \pm 51.84$ & $751.0 \pm 71.77^{b}$ & $1031.0 \pm 13.93^{b}$ & $872.4 \pm 13.81^{b}$ \\
\hline
\end{tabular}

The results are presented as mean \pm standard error of the mean. $\mathrm{n}=5 .{ }^{\mathrm{a}} \mathrm{P}>0.05 .{ }^{\mathrm{b}} \mathrm{P}<0.05$ vs. SOC group.

Table 5 - Effect of the sub-acute treatment (2 weeks) with $15 \mathrm{mg} / \mathrm{kg}$ Gymnema sylvestre (GS) twice a day (oral gavage) on blood level of glucose $(\mathrm{mg} / \mathrm{dL})$. triglycerides $(\mathrm{mg} / \mathrm{dL})$. body weight $(\mathrm{g})$. daily food $(\mathrm{g})$ and water intake $(\mathrm{mL})$ in non-diabetic rats.

\begin{tabular}{lr|r|r|r} 
& \multicolumn{2}{c|}{ COG } & \multicolumn{1}{c}{ GS } \\
\cline { 2 - 5 } & \multicolumn{1}{c}{ B T } & AT & \multicolumn{1}{c}{ B T } & AT \\
Glucose & $62.4 \pm 5.0$ & $56.3 \pm 7.2^{\mathrm{a}}$ & $62.6 \pm 4.9$ & $59.5 \pm 7.6^{\mathrm{a}}$ \\
Triglycerides & $74.0 \pm 6.5$ & $66.8 \pm 4.6^{\mathrm{a}}$ & $72.0 \pm 6.0$ & $65.6 \pm 7.1^{\mathrm{a}}$ \\
Body Weight & $277.7 \pm 7.4$ & $297.2 \pm 6.5^{\mathrm{a}}$ & $280.7 \pm 4.7$ & $286.9^{\mathrm{a}} \pm 5.8^{\mathrm{a}}$ \\
Water intake & $41.9 \pm 1.4$ & $42.5 \pm 1.8^{\mathrm{a}}$ & $42.2 \pm 1.7$ & $41.7 \pm 1.9^{\mathrm{a}}$ \\
Food intake & $27.8 \pm 0.9$ & $28.6 \pm 0.8^{\mathrm{a}}$ & $27.3 \pm 1.1$ & $26.2^{\mathrm{a}} \pm 0.8^{\mathrm{a}}$ \\
\hline
\end{tabular}

The results are presented as as mean \pm standard error of the mean. $\mathrm{n}=10 .{ }^{\mathrm{a}} \mathrm{P}>0.05$ if compared BT vs. AT for both groups.

Table 6 - Effect of the sub-acute treatment (2 weeks) with $15 \mathrm{mg} / \mathrm{kg}$ Gymnema sylvestre (GS) twice a day (oral gavage) on blood level of glucose $(\mathrm{mg} / \mathrm{dL})$. triglycerides $(\mathrm{mg} / \mathrm{dL})$. body weight $(\mathrm{g})$. daily food $(\mathrm{g})$ and water intake $(\mathrm{mL})$ in alloxan-diabetic rats.

\begin{tabular}{lr|r|r|r}
\hline & \multicolumn{2}{c|}{ COG } & \multicolumn{1}{c}{ GS } \\
\cline { 2 - 5 } BT & \multicolumn{1}{c}{ BT } & BT & AT \\
Glucose & $239.7 \pm 1.6$ & $241.3 \pm 1.7^{\mathrm{a}}$ & $237.3 \pm 1.6$ & $199.2 \pm 21.3^{\mathrm{a}}$ \\
Triglycerides & $110.8 \pm 14.7$ & $187.6 \pm 28.2^{\mathrm{b}}$ & $111.6 \pm 12.4$ & $105.7 \pm 21.8^{\mathrm{a}}$ \\
Body Weight & $197.3 \pm 9.0$ & $183.6 \pm 9.6^{\mathrm{a}}$ & $202.3 \pm 9.9$ & $189.0 \pm 9.8^{\mathrm{a}}$ \\
Water intake & $129.0 \pm 4.5$ & $140.3 \pm 6.6^{\mathrm{a}}$ & $141.1 \pm 9.9$ & $133.9 \pm 9.1^{\mathrm{a}}$ \\
Food intake & $39.4 \pm 3.4$ & $36.5 \pm 1.5^{\mathrm{a}}$ & $36.1 \pm 1.9$ & $34.4 \pm 2.3^{\mathrm{a}}$
\end{tabular}

The results are presented as mean \pm standard error of the mean. $n=10 .{ }^{a} \mathrm{P}>0.05 .{ }^{b} \mathrm{P}<0.05$ if compared BT vs. AT for both groups. 
Table 7 - Effect of the chronic treatment (4 weeks) with $15 \mathrm{mg} / \mathrm{kg}$ Gymnema sylvestre (GS) twice a day (oral gavage) on blood level of glucose $(\mathrm{mg} / \mathrm{dL})$. triglycerides $(\mathrm{mg} / \mathrm{dL})$. body weight $(\mathrm{g})$. daily food $(\mathrm{g})$ and water intake $(\mathrm{mL})$ in normal and alloxan-diabetic rats.

\begin{tabular}{lrr|r|r}
\hline & \multicolumn{2}{c|}{ COG } & \multicolumn{1}{c}{ GS } & \multicolumn{1}{c}{ AT } \\
\cline { 2 - 5 } GT & \multicolumn{1}{c}{ BT } & \multicolumn{1}{c}{ BT } & $211.9 \pm 8.3^{\mathrm{a}}$ \\
Triglycerides & $60.7 \pm 3.9$ & $60.0 \pm 5.7^{\mathrm{a}}$ & $222.6 \pm 3.5$ & $118.4 \pm 22.0^{\mathrm{a}}$ \\
Body Weight & $65.8 \pm 4.9$ & $63.8 \pm 8.9^{\mathrm{a}}$ & $146.7 \pm 15.2$ & $214.9 \pm 8.4^{\mathrm{a}}$ \\
Water intake & $301.6 \pm 7.8$ & $291.0 \pm 5.2^{\mathrm{a}}$ & $201.7 \pm 9.6$ & $139.8 \pm 6.4^{\mathrm{a}}$ \\
Food intake & $40.7 \pm 0.9$ & $43.1 \pm 2.0^{\mathrm{a}}$ & $127.8 \pm 3.1$ & $36.8^{\mathrm{a}} \pm 1.8^{\mathrm{a}}$ \\
\hline
\end{tabular}

The results are presented as mean \pm standard error of the mean. $\mathrm{n}=10 .{ }^{\mathrm{a}} \mathrm{P}>0.05$ if compared COG vs. GS for both groups.

\section{ACKNOWLEDGMENTS}

This work was supported by grants from Herbarium Laboratories and CNPq (400075/2002-0).

\section{RESUMO}

Neste estudo foi investigado o potencial antidiabético e hipolipemiante da Gymnema sylvestre (GS). O efeito agudo da GS administrada via oral sobre a glicemia e lipidemia foi avaliado em ratos Wistar sob as seguintes condições: a) após refeição balanceada; b) após ingestão de 1000 mg de amylose ou $1000 \mathrm{mg} / \mathrm{kg}$ de glicose; c) após ingestão de uma mistura de $12 \mathrm{~mL} / \mathrm{kg}$ de óleo de soja $+1 \%$ de colesterol (OSC). Foi avaliado também o efeito do tratamento com GS durante duas (sub-agudo) ou quatro semanas (crônico) sobre o peso corporal, ingestão de água e alimento, glicemia e lipidemia em ratos não diabéticos e diabéticos induzidos com aloxana. A dose de GS utilizada na maioria dos experimentos $(30 \mathrm{mg} / \mathrm{kg})$ corresponde a dose empregada para tratar diabetes no Brasil. A administração aguda de GS não influenciou a elevação da glicemia durante a refeição balanceada, administração de amilose ou glicose; mas intensificou a elevação da concentração sérica de lipídeos após a administração de OSC. Além disso, o tratamento sub-agudo e crônico com GS em ratos não diabéticos e diabéticos induzidos com aloxana não alterou: a) o ganho de peso corporal; b) a ingestão de água e alimento; c) os níveis de glicose e lipídios. Assim sendo, a Gymnema sylvestre pelo menos na forma comercializada no Brasil (folhas secas em pó) requer mais ensaios experimentais e clínicos antes de ser recomendada para tratamento do diabetes e hiperlipidemia.

\section{REFERENCES}

Allain, C. C.; Poon, L. S.; Chan, C. S.; Richmond, W. and $\mathrm{Fu}, \mathrm{P} . \mathrm{C}$. (1974), Enzymatic determination of total serum cholesterol. Clin Chem., 20, 470-5.

Bailey, C. J. and Day, C. (1989), Traditional plant medicines as treatments for diabetes. Diabetes Car., 12, 553-63.

Baskaran, K.; Ahmath, B. K.; Shanmugasundaram, K. R. and Shanmugasundaram, E. R. B. (1990), Antidiabetic effect of the leaf extract from Gymnema sylvestre in insulin-dependent diabetes mellitus patients. J. Ethnopharmacol., 30, 295-300.

Bazotte, R. B.; Batista, M. R. and Curi, R. (2000), Meal-feeding scheme: twenty years of research in Brazil. Braz. J. Med. Biol. Res., 33, 985-91.

Bergmeyer, H. U. and Bernt, E. (1974), Determination of glucose with glucose-oxidase and peroxidase. In: Bergmeyer, H. U. (ed.). Methods of Enzymatic Analysis. New York : Verlag Chemie-Academic Pres. pp. 1205-15.

Bucolo, G. and David, H (1973), Quantitative determination of serum triglycerides by the use of enzymes. Clin. Chem., 19, 476-82.

Chattopadhyay, R. R. (1998), Possible mechanism of antihyperglycemic effect of Gymnema ylvestre Leaf extract: part 1. Gen Pharmac., 31, 495-6.

Chattopadhyay, R. R. (1999), A comparative evaluation of some blood sugar lowering agents of plant origin. J. Ethnopharmacol., 67, 367-72.

Day, C. (1998), Traditional plant treatments for diabetes mellitus: pharmaceutical foods. Br. J. Nutr., 80, 5-6.

Grover, J. K.; Yadav, S. and Vats, V. (2002), Medicinal plants of India with anti-diabetic potential. $J$. Ethnopharmacol., 81, 81-100.

Hirata, S.; Abe, T. and Imoto, T. (1992), Effect of crude gymnemic acid on oral glucose tolerance test in human being. J. Yonago Med Assoc., 43, 392-6. 
Kar, A.; Choudhary, B. K. and Bandyopadhyay, N. G. (1999), Preliminary studies of the inorganic constituents of some indigenous hypoglycaemic herbs on oral glucose tolerance test. J. Ethnopharmacol., 64, 179-84.

Kar, A.; Choudhary, B. K. and Bandyopadhyay, N. G. (2003), Comparative evaluation of hypoglycaemic activity of some Indian medicinal plants in alloxan diabetic rats. J. Ethnopharmacol., 84, 105-8.

Murakami, N.; Murakami, T.; Kadoya, M.; Matsuda, H.; Yamahara, J. and Yoshikawa, M. (1996), New hypoglycemic constituents in "gymnemic acid" from Gymnema sylvestre. Chem. Pharm. Bull., (Tokyo), 44, 469-71.

Okabayashi, Y.; Tani, S.; Fujisawa, T.; Koide, M.; Hasegawa, H.; Nakamura, T.; Fujii, M. and Otsuki, M (1990), Effect of Gymnema sylvestre. R. Br. on glucose homeostasis in rats. Diabetes Res. Clin. Pract., 9, 143-8.

Persaud, S. J.; Al-Majed, H.; Raman, A. and Jones, P. M. (1999), Gymnema sylvestre stimulates insulin release in vitro by increased membrane permeability. J. Endocrinol., 163, 207-12.

Postma, T. and Stroes, J. A. (1968), Lipid screening in clinical chemistry. Clin. Chim. Acta., 22, 569-78.

Shanmugasundaram, K. R.; Panneerselvam, C.; Samudram, P. and Shanmugasundaram, E. R. B. (1983), Enzyme changes and glucose utilisation in diabetic rabbits: the effect of Gymnema sylvestre. R. Br. J. Ethnopharmacol., 7, 205-34.

Shanmugasundaram, E. R. B.; Gopinath, K. L.; Shanmugasundaram, K. R. and Rajendran, V. M. $\left(1990_{a}\right)$, Possible regeneration of the islets of Langerhans in streptozotocin-diabetic rats given Gymnema sylvestre leaf extracts. J. Ethnopharmacol., 30, 265-79.

Shanmugasundaram, E. R. B.; Rajeswari, G.; Baskaran, K.; Kumar, R. B. R.; Shanmugasundaram, K. R. and Ahmath, B. K. (1990b), Use of Gymnema sylvestre leaf extract in the control of blood glucose in insulindependent diabetes mellitus. J. Ethnopharmacol., 30, 281-94.

Shigematsu, N.; Asano, R.; Shimosaka, M. and Okazaki, M. (2001 a . Effect of long termadministration with Gymnema sylvestre R. BR on plasma and liver lipid in rats. Biol. Pharm. Bull., 24, 643-9.

Shigematsu, N.; Asano, R.; Shimosaka, M. and Okazaki, M. $\left(2001_{\mathrm{b}}\right)$, Effect of administration with the extract of Gymnema sylvestre R. Br leaves on lipid metabolism in rats. Biol. Pharm. Bull., 24, 713-7.
Shimizu, K; Iino, A.; Nakajima, J.; Tanaka, K.; Nakajyo, S.; Urakawa, N.; Atsuchi, M.; Wada T. and Yamashita, C. (1997), Suppression of glucose absorption by some fractions extracted from Gymnema sylvestre leaves. J. Vet. Med. Sci., 59, 245-51.

Souza, H. M.; Borba-Murad, G. R.; Ceddia, R. B.; Curi, R.; Vardanega-Peicher, M. R. and Bazotte, R. B. (2001), Rat liver responsiveness to gluconeogenic substrates during insulin-induced hypoglycemia. Braz. J. Med. Biol. Res., 34, 771-7.

Sugihara, Y.; Nojima, H.; Matsuda, H.; Murakami, T.; Yoshikawa, M. and Kimura, I. (2000), Antihyperglycemic effects of gymnemic acid IV. a compound derived from Gymnema sylvestre leaves in streptozotocin-diabetic mice. J. Asian Nat. Prod. Res., 2, 321-7.

Wang, L. F.; Luo, H.; Miyoshi, M.; Imoto, T.; Hiji, Y. and Sasaki, T. (1998), Inhibitory effect of gymnemic acid on intestinal absorption of oleic acid in rats. Can. J. Physiol. Pharmacol., 76, 1017-23.

Yoshikawa, M.; Murakami, T.; Kadoya, M.; Li, Y.; Murakami, N.; Yamahara, J. and Matsuda, H. (1997a), Medicinal foodstuffs. IX. The inhibitors of glucose absorption from the leaves of Gymnema sylvestre R. BR. (Asclepiadaceae): structures of gymnemosides a and b. Chem. Pharm. Bull., (Tokyo), 45, 1671-6.

Yoshikawa, M.; Murakami, T. and Matsuda, H. $\left(1997_{b}\right)$, Medicinal foodstuffs. X. Structures of new triterpene glycosides. gymnemosides-c. -d. -e. and -f. from the leaves of Gymnema sylvestre $\mathrm{R}$. Br.: influence of gymnema glycosides on glucose uptake in rat small intestinal fragments. Chem. Pharm. Bull., (Tokyo), 45, 2034-8.
Received: May 12, 2003; Revised: October 08, 2003; Accepted: February 20, 2004. 